\section{Aging Migrants}

Albert Sabater

Serra Húnter Fellow at the Faculty of Business and Economic Sciences, University of Girona, Girona, Spain

\section{Synonyms}

Aging and immigration; Aging and migration; Aging immigrants; Older immigrants; Older migrants; Transnational aging

\section{Definition}

The term "aging migrants" usually refers to individuals who are foreign-born and are growing old in a country of destination other than that of his or her country of birth so that the country of destination has become his or her country of residence. In most cases, aging migrants are not foreign nationals as they may have lived in the country of destination for decades. In some cases, aging migrants are not international migrants and are represented by internal migrants who move within a country seasonally or away from informal care by family members and others to institutional care in different states or regions. Although definitions vary by countries and studies, migrants aged 50 or older are commonly considered as "aging migrants," either because many retirement migrants occur well before the conventional delimiter (65 years) or because many international (labor) migrants tend to experience job-related illness, disability, or redundancy in their 50 s or before.

\section{Overview}

In most countries, the aging of migrants is an ongoing and growing phenomenon. The emergence of large numbers of aging migrants is subject to considerable diversity in characteristics such as the historical time of migration (recent or past migration), the age at migration of older persons (during early life, middle adulthood, or in later life), the conditions under which the migration trajectory developed, and the countries or places where they settle. Migration involves the distribution of people within and between countries and is one of the most important factors shaping spatial difference in demographic structures. In most countries, the mosaic of past types of migration as a result of colonial legacies, the recruitment of "temporary" workers, the steady growth of retirement migration or undocumented migration, including those in precarious legal status or other difficult circumstances such as older refugees and asylum seekers, is crucial to explain the various types of "aging migrants" across the world. 


\section{Key Research Findings}

Migration has increasingly become a typical facet of modern society and the migration process has been recognized, even in the best possible circumstances, as a stressful life event (Coffman 1987). Hence, there are inevitable concerns over the well-being of significant numbers of aging migrants as well as a desire to maximize the opportunities afforded by healthy engaged senior migrants (Warnes and Williams 2006). Within this context, although research on older migrants has grown significantly since the turn of the century, the issue of growing old in a second homeland still remains a topic largely underdeveloped. Since migration entails a dramatic change in social environments and various aspects of one's biography, so far the majority of studies have focused on the traditional social stratification framework for understanding well-being differences between aging migrants and senior native-born populations in three specific domains: (1) health;

(2) housing and living arrangements; and (3) return migration.

Studies on health generally highlight how aging migrants in Europe have worse health and are frailer in comparison to their native counterparts (Solé-Auró and Crimmins 2008; Reus-Pons et al. 2018; Walkden et al. 2018). Outcomes are generally associated with multiple factors ranging from socioeconomic, behavioral to psychosocial and environmental (Evandrou 2000; Lindstrom et al. 2001; Adelman et al. 2009), with immigrant health also depending on the country of origin and sex (Oksuzyan et al. 2019). Research on the association between poor health and socioeconomic status at older ages among minority groups remains dominant but fragmented as the health status of some groups is less sensitive to their socioeconomic circumstances than others (Graham 2005; Nazroo 2003). There is some consensus that, while immigrants tend to be healthier than might be expected given their social status at the time of immigration (Razum et al. 2000; Riosmena et al. 2013), the health advantage on arrival is known to decrease with length of residence in the country of destination (Stronks 2003), with ill-health being more marked with increasing age among migrants/minorities (Nazroo 2006). It has been argued that the superior physical health advantage of immigrants may be more or less important depending on two major aspects (Mirowsky and Ross 1980). From a minority-status perspective, immigrants tend to occupy disadvantaged positions in the social structure, and the chronic social stressors associated with these positions produce distress. From this perspective, recent research demonstrates that, were not for family social capital, older immigrants might experience much worse health outcomes, particularly poorer mental health (Sabater and Graham 2016). From an ethnic-cultural perspective, it is also expected that differences in beliefs, values, and patterns of living produce different distress levels. Although research has also placed a great deal of emphasis on the meaning of illness among ethnic and immigrant groups, implying different perceptions on the combined physical and psychological health (Ebrahim 1992; McGee et al. 1999), the existing evidence is rather inconclusive with critics' main concern being that such explanations obscure the impact of structural factors on immigrant health disparities (Viruell-Fuentes et al. 2012). Meanwhile, research examining the health and health care needs of international migrants retiring to different destinations has received less attention. The prominence of studies of the so-called "lifestyle migration" (Benson and O'Reilly 2009) for "self-fulfilment" or the "good life" (Oliver 2012) has clearly overshadowed research on the language, cultural, spatial, and financial barriers that an increasing number of older retirees living abroad may face, especially when they require additional support and care as a result of declining health and frailty (Hall and Hardill 2016).

Another domain that is common within the research on senior migrants is housing conditions and living arrangements. Among international migrants aging in place, substandard housing and a persistent homeownership gap between aging migrants and natives are generally the norm (Green et al. 2009), with many living in deprived neighborhoods (Bonvalet and Ogg 2008) and experiencing greater neighborhood segregation than younger groups (Sabater and 
Catney 2019). While it is argued that living in homogenous neighborhoods with other family members and supportive communities may provide sociocultural benefits that protect aging migrants against health decline (Eschbach et al. 2004) and mental health disorders (Bécares et al. 2018), there are also risks of vulnerability for those living in overcrowded conditions or with the extended family as the main caregivers. Such vulnerabilities may have negative repercussions on family relationships and alter family ties in times of hardship such as illness (Martineau and Plard 2019), and may also lead to an increased risk of contracting infectious diseases, including COVID-19, due to the difficulty of following physical distancing advice (Kluge et al. 2020).

The picture for international retiree migrants differs considerably. They are mostly property owners in planned retirement communities who finance their residential moves by selling metropolitan homes in exchange for improved lifestyle outcomes (Warnes et al. 2004). Living arrangements are generally seen as a function of preferences, resources, and needs, as well as availability of children (Wilmoth 2000). Thus, research has revealed remarkable differences in living arrangements among aging migrants, and multigenerational families are vital economic and social safety nets for immigrants (Silverstein and Attias-Donfut 2010) with older immigrants more likely than their counterparts to live in multigenerational households (Kritz et al. 2000). Indeed, extended family living arrangements are still much more common among migrants than in the rest of the population, and various kinds of extended family connections usually dominate even though the majority of ethnic groups are moving toward a more individualistic approach (Berthoud 2005). However, as Smart and Shipman (2004) note, it may be too simplistic to view different ethnic groups in terms of their position between modern individualism and traditionalism as this implies a deviation from the norm when distinctive cultural traditions and socioeconomic pressures are shaping family patterns too (Van Hook and Glick 2007).

Finally, another key theme of the relevant literature relates to return migration. Although international migrants aging in place may opt to return to their countries of origin, the existing evidence supports the idea of myth of return (Anwar 1979), with only a minority embarking on that journey (Bolzman et al. 2006; Ciobanu and Ramos 2015; Hunter 2011) while many more engaging in "long-distance thinking and care-giving" (Baldassar et al. 2007; Horn et al. 2016; Karl et al. 2017; Torres et al. 2016) by making use of information and communications technology (Baldassar et al. 2016; Hunter 2015). However, the return of migrants is still an issue that creates expectations for both host populations and migrants and sometimes is used as a strategy, whereby the idea of return is delayed but not abandoned (Brockmann and Fisher 2001). The general picture across many countries is that fewer have gone back than expected (King 1986; Rendall and Ball 2004; White 2006). Some studies suggest that health status can act as a factor when taking the decision to move abroad as well as influencing how long a migrant stays in the host country (Legido-Quigley and La Parra 2007). Undoubtedly, the ability to access health and care provision is an important issue with regard to return migration (Burholt et al. 2016; Horn and Schweppe 2015). Another key issue is whether aging migrants have adult children living in the host or in the sending country, which may also determine the parental intention to return (de Coulon and Wolff 2010). The latter constitutes one of the factors recently considered within the study of older migrants and their (im)mobilities (Ciobanu and Hunter 2017).

\section{Future Directions of Research}

The current situation reveals further understanding is needed with regard to the principal personal, societal and welfare implications of the growing number of aging migrants. While various studies have paid attention to the growing numbers and lives of aging migrants, a number of key aspects remain clearly under-researched. First, it is necessary to deepen our understanding of the components and correlates that impact the well-being conditions of aging migrants at different stages 
of the life course and across countries by taking into consideration their social history, including the linkages between restrictive entry, integration policies, and migrant health outcomes (Juárez et al. 2018), as well as the interdependence in relationships (Hagestad and Settersten 2016). The latter includes how ageing migrants fare during their adult children's absences, particularly in contexts of very weak institutional support and widespread poverty and inequality. Second, it is also fundamental to take into account that the process of aging is culturally determined (Torres 1999), thus the growing number of senior migrants over future years not only in highincome countries but also in low- and middleincome countries will represent a crucial structural shift for both the normalization of the lives of the populations involved and in relation to the general and specific responses needed in terms of health care and other support. Since aging migrants are also increasingly heterogenous in terms of health, economic conditions, and lifestyles, it will be essential to advance our understanding of the diversity between and within aging migrant groups.

\section{Cross-References}

\author{
- Aging Rogues \\ - Covid-19 and Healthy Aging \\ - Global Aging on Aging \\ - Health Disparities Among Aging Migrants \\ Housing \\ - Living Arrangement in Later Life \\ - Social Housing
}

\section{References}

Adelman S, Blanchard M, Livingston G (2009) A systematic review of the prevalence and covariates of dementia or relative cognitive impairment in the older African-Caribbean population in Britain. Int $\mathrm{J}$ Geriatr Psychiatry 24:657-665

Anwar M (1979) The myth of return: Pakistanis in Britain. Heinemann, London

Baldassar L, Wilding R, Baldock C (2007) Long-distance care-giving: transnational families and the provision of aged care. In: Paoletti I (ed) Family caregiving for older disabled people: relational and institutional issues. Nova Science, New York, pp 201-227

Baldassar L, Nedelcu M, Merla L, Wilding R (2016) ICTbased co-presence in transnational families and communities: challenging the premise of face-to-face proximity in sustaining relationships. Global Netw 16 (2): 133-144

Bécares L, Dewey ME, Das-Munshi J (2018) Ethnic density effects for adult mental health: systematic review and meta-analysis of international studies. Psychol Med 48(12):2054-2072

Benson M, O'Reilly K (2009) Migration and the search for a better way of life: a critical exploration of lifestyle migration. Sociol Rev 57(4):608-625

Berthoud R (2005) Family formation in multi-cultural Britain: diversity and change. In: Loury GC et al (eds) Ethnicity, social mobility and public policy: comparing the US and the UK. Cambridge University Press, Cambridge, pp 222-252

Bolzman C, Fibbi R, Vial M (2006) What to do after retirement? Elderly migrants and the question of return. J Ethn Migr Stud 32(8):1359-1375

Bonvalet C, Ogg J (2008) The housing situation and residential strategies of older people in France. Ageing Soc 28(6):753-777

Brockmann M, Fisher M (2001) Older migrants and social care in Austria. J Eur Soc Policy 11(4):353-362

Burholt V, Dobbs C, Victor C (2016) Transnational relationships and cultural identity of older migrants. GeroPsych 29(2):57-69

Ciobanu RO, Hunter A (2017) Older migrants and (im) mobilities of ageing: an introduction. Popul Space Place 23(5):e2075

Ciobanu RO, Ramos AC (2015) Is there a way back? A state-of-the-art review of the literature on retirement return migration. In: Karl U, Torres S (eds) Ageing in contexts of migration. Routledge, London, pp 116-127

Coffman TL (1987) Relocation and relocation stress. In: Maddox GL (ed) Encyclopedia of aging. Springer, New York, pp 563-564

de Coulon A, Wolff FC (2010) Location intentions of immigrants at retirement: stay/return or go "back and forth"? Appl Econ 42(26):3319-3333

Ebrahim S (1992) Health and ageing within ethnic minorities. Jessica Kingsley Publishers, London

Eschbach K, Ostir GV, Patel KV, Markides KS, Goodwin JS (2004) Neighborhood context and mortality among older Mexican Americans: is there a barrio advantage? Am J Public Health 94(10):1807-1812

Evandrou M (2000) Ethnic inequality in health in later life. Health Stat Q 8(Winter):20-28

Graham H (2005) Intellectual disabilities and socioeconomic inequalities in health: an overview of research. J Appl Res Intellect Disabil 18:101-111

Green M, Evandrou M, Falkingham J (2009) Older international migrants: who migrates to England and Wales in later life? Popul Trends 137:33-40 
Hagestad GO, Settersten RA Jr (2016) Aging: it's interpersonal! Reflections from two life course migrants. Gerontologist 57(1):136-144

Hall K, Hardill I (2016) Retirement migration, the "other" story: caring for frail elderly British citizens in Spain. Ageing Soc 36(3):562-585

Horn V, Schweppe C (eds) (2015) Transnational aging: current insights and future challenges. Routledge, London

Horn V, Schweppe C, Bender D, Hollstein T (2016) Moving (for) elder care abroad: the fragile promises of old age care facilities for elderly Germans in Thailand. In: Horn V, Schweppe C (eds) Transnational aging: current insights and future challenges. Routledge, London, pp 163-177

Hunter A (2011) Theory and practice of return migration at retirement: the case of migrant worker hostel residents in France. Popul Space Place 17(2):179-192

Hunter A (2015) Empowering or impeding return migration? ICT, mobile phones, and older migrants' communications with home. Global Netw 15(4):485-502

Juárez SP, Honkaniemi H, Dunlavy AC, Aldridge RW, Barreto ML, Katikireddi SV, Rostila M (2018) The impacts of non-health-targeted policies on migrant health: a systematic review and meta-analysis. Lancet Glob Health. https://doi.org/10.1016/S2214-109X(18) 30560-6

Karl U, Ramos AC, Kühn B (2017) Older migrants in Luxembourg - care preferences for old age between family and professional services. J Ethn Migr Stud 43 (2):270-286

King R (1986) Return migration and regional economic problems. Croom Helm, London

Kluge HHP, Jakab Z, Bartovic J, D'Anna V, Severoni S (2020) Refugee and migrant health in the COVID-19 response. Lancet 395(10232):1237-1239

Kritz MM, Gurak DT, Chen L (2000) Elderly immigrants: their composition and living arrangements. J Sociol Soc Welf 27:85-114

Legido-Quigley H, La Parra D (2007) The health care needs of UK pensioners living in Spain: an agenda for research. Eurohealth 13(4):14-17

Lindstrom M, Sundquist J, Ostergren PO (2001) Ethnic differences in self-reported health in Malmo in southern Sweden. J Epidemiol Community Health 55:97-103

Martineau A, Plard M (2019) Are elderly immigrants meeting the challenges of successful aging? Review of literature on the aging of elderly migrants in France. Cybergeo: Eur J Geogr. https://doi.org/10.4000/ cybergeo.33224

McGee DL, Liao Y, Cao G, Cooper RS (1999) Selfreported health status and mortality in a multiethnic US cohort. Am J Epidemiol 149(1):41-46

Mirowsky J, Ross CE (1980) Minority status, ethnic culture, and distress: a comparison of Blacks, Whites, Mexicans, and Mexican Americans. Am J Sociol 86 (3):479-495
Nazroo JY (2003) The structuring of ethnic inequalities in health: economic position, racial discrimination, and racism. Am J Public Health 93(2):277-284

Nazroo JY (2006) Ethnicity and old age. In: Vincent JA, Phillipson C, Downs M (eds) The futures of old age. Sage, London

Oksuzyan A, Mussino E, Drefahl S (2019) Sex differences in mortality in migrants and the Swedish-born population: is there a double survival advantage for immigrant women? Int J Public Health 64(3):377-386

Oliver C (2012) Retirement migration: paradoxes of ageing. Routledge, London

Razum O, Zeeb H, Rohrmann S (2000) The "healthy migrant effect" - not merely a fallacy of inaccurate denominator figures. Int J Epidemiol 29:191-192

Rendall MS, Ball DJ (2004) Immigration, emigration and the ageing of the overseas-born population in the United Kingdom. Popul Trends 116:18-27

Reus-Pons M, Mulder CH, Kibele EU, Janssen F (2018) Differences in the health transition patterns of migrants and non-migrants aged 50 and older in southern and western Europe (2004-2015). BMC Med 16(1):57

Riosmena F, Wong R, Palloni A (2013) Migration selection, protection, and acculturation in health: a binational perspective on older adults. Demography 50 (3):1039-1064

Sabater A, Catney G (2019) Unpacking summary measures of ethnic residential segregation using an age group and age cohort perspective. Eur J Popul 35 (1): $1-29$

Sabater A, Graham E (2016) The role of children's education for the mental health of aging migrants in Europe. GeroPsych 29(2):81-92

Silverstein M, Attias-Donfut C (2010) Intergenerational relationships of international migrants in developed nations: the United States and France. In: Dannefer D, Phillipson C (eds) The Sage handbook of social gerontology. Sage, London, pp 177-189

Smart C, Shipman B (2004) Visions in monochrome: families, marriage and the individualization thesis. $\mathrm{Br} \mathrm{J}$ Sociol 55(4):491-509

Solé-Auró A, Crimmins EM (2008) Health of immigrants in European countries. Int Migr Rev 42(4):861-876

Stronks K (2003) Public health research among immigrant populations: still a long way to go. Eur J Epidemiol 18 (9):841-842

Torres S (1999) A culturally-relevant theoretical framework for the study of successful ageing. Ageing Soc 19(1):33-51

Torres S, Ågård P, Milberg A (2016) The "other" in end-oflife care: providers' understandings of patients with migrant backgrounds. J Intercult Stud 37(2):103-117

Van Hook J, Glick J (2007) Immigration and living arrangements: moving beyond economic need versus acculturation. Demography 44(2):225-249

Viruell-Fuentes EA, Miranda PY, Abdulrahim S (2012) More than culture: structural racism, intersectionality theory, and immigrant health. Soc Sci Med 75 (12):2099-2106 
Walkden GJ, Anderson EL, Vink MP, Tilling K, Howe LD, Ben-Shlomo Y (2018) Frailty in older-age European migrants: cross-sectional and longitudinal analyses of the Survey of Health, Aging and Retirement in Europe (SHARE). Soc Sci Med 213:1-11

Warnes A, Williams A (2006) Older migrants in Europe: a new focus for migration studies. J Ethn Migr Stud 32 (8):1257-1281
Warnes AM, Friedrich K, Kellaher L, Torres S (2004) The diversity and welfare of older migrants in Europe. Ageing Soc 24:307-326

White P (2006) Migrant populations approaching old age: prospects in Europe. J Ethn Migr Stud 32(8):12831300

Wilmoth J (2000) Unbalanced social exchanges and living arrangement transitions in later life. The Gerontologist 40:64-74 